9 Taggart C, O'Grady J, Stevenson M, Hand E, Mc Clelland R, Kelly C. Accuracy of diagnosis and routine psychiatric assessment in patients presenting to an accident and emergency department. Gen Hosp Psychiatry 2006; 28: 330-5.

10 Manoranjitham SD, Rajkumar AP, Thangadurai P, Prasad J, Jayakaran R, Jacob KS. Risk factors for suicide in rural south India. Br J Psychiatry 2010; 196: $26-30$

11 Casey P, Maracy M, Kelly BD, Lehtinen V, Ayuso-Mateos JL, Dalgard OS, et al Can adjustment disorder and depressive disorder be distinguished? Results from ODIN. J Affect Disord 2006; 92: 291-7.

12 Strain J, Diefenbacher A. The adjustment disorders: the conundrums of the diagnoses. Compr Psychiatry 2008; 49: 121-30.

13 Olfson M, Marcus SC. National patterns in antidepressant medication treatment. Arch Gen Psychiatry 2009; 66: 848-56.

14 de Leo D. Treatment of adjustment disorders: a comparative evaluation. Psychol Rep 1989; 64: 51-4.
15 Baumeister H, Maercker A, Casey P. Adjustment disorders with depressed mood: A critique of its DSM-IV and ICD-10 conceptualization and recommendations for the future. Psychpathology 2009; 42: 139-47.

16 Maercker A, Forstmeier S, Pielmaier L, Spangenberg L, Brähler E, Glaesmer $\mathrm{H}$. Adjustment disorders: prevalence in a representative nationwide survey in Germany. Soc Psychiatry Psychiatr Epidemiol 2012; Mar 11 (Epub ahead of print).

17 Slade T, Andrews G. Latent structure of depression in a community sample: a taxometric analysis. Psychol Med 2005; 35: 489-97.

18 Wing JK, Babor T, Brugha T, Burke J, Cooper JE, Giel R, et al. SCAN. Schedules for Clinical Assessment in Neuropsychiatry. Arch Gen Psychiatry 1990; 47: 589-93.

19 Strain JJ, Freidman MS. Considering adjustment disorders as stress response syndromes. Depress Anxiety 2011; 28: 818-23.

20 McHugh PR, Slavney PR. Mental illness - comprehensive evaluation or checklist? N Engl J Med 2012; 366: 1853-55.

\title{
psychiatry in theatre
}

\section{King Lear by William Shakespeare: first performed 1606}

\section{Jo Richards}

The tragic drama of King Lear charts the deteriorating mental health of the main character Lear in five acts. This process is linked to his older daughters' rejection and cruelty towards him. The final scenes include Lear's recovery through reconciliation with his youngest daughter before their deaths.

In Act I Lear recognises his own fragile psychological state ' $\mathrm{O}$, let me not be mad, not mad, sweet heaven! Keep me in temper; I would not be mad'. These lines, uttered by an elderly man, speak across the centuries and generations. The repetition of the word 'mad' evokes the strength of Lear's anxiety. His intense fear of losing touch with reality is familiar to contemporary psychiatrists, echoing what they hear from their patients. Lear's progression into mental ill health is accompanied by other transformations. In Act III, he questions the plight of the homeless because of the hardship he himself experiences while seeking shelter during the storm: 'How shall your houseless heads and unfed sides ... defend you/From seasons such as these? $\mathrm{O}, \mathrm{I}$ have ta'en/Too little care of this'. These lines reveal Lear becoming a more reflective, empathic individual. The theme of 'madness' continues. For example, the character Tom is 'disguised as a madman'. The association between homelessness and mental ill health is made explicit by The Fool, who accompanies Lear: 'This cold night will turn us all to fools and madmen'. This chilling line remains as relevant today as in the early 17 th century.

Lear becomes increasingly eccentric during Act IV. His appearance, 'fantastically dressed with wild flowers' signals mental illness. His speech is difficult to follow, even taking account of the 400-year-old terminology: 'Nature's above art in that respect. There's your press money. That fellow handles his bow like a crow-keeper. Draw me a clothier's yard. Look, look a mouse!'. The speech composition here is reminiscent of formal thought disorder, a phenomenon described 200 years later by psychiatrists. The other characters' responses confirm that Lear is becoming incoherent to a Jacobean as well as 21st-century audience. We can all relate to Gloucester's sad reaction to Lear's behaviour and manner of speech: 'O ruined piece of nature'.

Lear acquires insights into society in Act IV, alongside his failing mental health. He comments on how wealth allows concealment of wrongdoing: 'Through tattered clothes small vices do appear; Robes and furred gowns hide all'. When Edgar replies 'Reason in madness!', he voices an impression not uncommonly shared by those in contact with individuals developing mental illness.

The play conveys how worsening mental health can be accompanied by increased perceptiveness. The other characters' voices describe how they observe and share Lear's experiences. King Lear stands the test of time as an effective means of exposing psychological processes and human relationships. Shakespeare's play remains relevant to today's psychiatric practice.

Jo Richards is a consultant psychiatrist. 